\title{
Sociology and Education in an Academic Career
}

\author{
Sandro Serpa \\ Faculty of Social and Human Sciences, Department of Sociology, University of the Azores, Floor 2, Office D.187, Rua da Mãe de Deus, \\ 9501-855 Ponta Delgada, São Miguel - the Azores, Portugal \\ Correspondence to: Dr. Sandro Serpa, Ph.D., Email: sandro.nf.serpa@uac.pt \\ DOI: https://doi.org/10.15354/si.21.fl005 \\ The authors declare no competing interest.
}

\begin{abstract}
The feature of life that follows aims to reflect on some topics that emerge from my 20 years of academic life, always in deep articulation between Sociology and Education. Without pretending to be thorough, the following topics emerge: the dialogue between sciences; interaction between people; organization and, at the same time, preparedness for the unexpected; classes with an active component; the importance of general culture; the need for permanent updating; publishing implies knowledge systematization; open access as an inevitability in scientific publication.
\end{abstract}

Keywords: Academic Career; Sociology; Education; Research; Academic Editor

Science Insights, 2021 May 21; Vol. 37, No. 2, pp.277-280.

(C) 2021 Insights Publisher. All rights reserved. (c) (i) $(5)$ Creative Commons Non Commercial CC BY-NC: This article is distributed under the terms of the Creative Commons Attribupermission provided the original work is attributed by the Insights Publisher.

\section{Introduction}

$\mathrm{H}$ AVING, predictably, reached about half of my academic career, which started in 2000 at the University of the Azores in Portugal, the feature of life that follows aims to reflect on some topics that emerge from my 20 years of academic life (1) in an exercise of self-reflexivity (2).

In this reflection, which necessarily has a strong personal brand (3), I hope not to "be breaking open doors" (2), in the sense that it may be too obvious, simplistic or uninteresting. I hope to articulate discursive rigor $(4,5)$ with the presentation of some of my personal stances (6), but always without mixing judgments of fact with judgments of value in the classical and, to some extent, timeless Weberian sense $(7,8)$ : “[ $[.$.$] after the$ quality and relevance of personal argumentation is assessed, should take place even without respecting the replication of the research model" (6) (pp.1).

To attain the aim of this text that focuses on academic life (9), through an autobiographical method as a form of self-training (10) and which consists of "The production of the self-narrative, via narrative exercise, [which] allows subjects to reflect on the temporal inscriptions of their existence. The narrative produced is, at the same time, a way of accessing the singu- larity of a life and the expression of social and historical times. The subject produced in the narrative is, simultaneously, singular and plural" (11) (pp.12), I will focus on some aspects of the academic career $(12,13)$ such as Sociology and Education, scientific research and dissemination. The text closes with a conclusion of this whole reflection.

\section{Academic Life}

In summary of my professional career, I am a higher education faculty member since 2000, having completed in 2013 the $\mathrm{PhD}$ in Education - Sociology of Education. I have teaching experience in areas such as Research, Sociology, Kindergarten Teachers Training, and Organizations, among others. Currently, I am particularly interested in Teaching Sociology, Digital Literacy, and Digital Organizations and Society

(https://www.cienciavitae.pt/portal/4E19-BF24-A0CA;

https://orcid.org/0000-0003-4286-4440).

Coming from the area of Sociology of Education, I became interested in organizations, especially in the organizational culture $(14,15)$. Contrary to common judgement, neither the school process, at its various levels, nor its transformation is easily learned as advocated by many common sense discourses (16). I 
have learned that, in practice, almost anyone thinks they are "specialists" in schooling/education, contrary to what happens in other scientific areas.

My entire academic career was shaped by the professional need to establish a deep and fruitful dialogue, predominantly between the scientific area of Sociology and Education (17, 18, 19, 20), and even within Sociology, inasmuch that, professionally, my basic training is Sociology but it was necessary to articulate it with teaching, especially at the beginning, when I joined the Department of Educational Sciences (21). Over time, both in teaching and research, I understood from experience the richness and urgency of the dialogue between sciences as being critical to allow, on the one hand, a better understanding of reality and, on the other hand, a more complete training of the students.

My inclusion in a higher education organization implied, both at the beginning and throughout this period, more or less formal interaction with other people, for example, in management, namely directors, colleagues, administrative staff, students, individuals outside the University who needed to be contacted. This interaction is unavoidable even if, more recently, digital technologies have, to some extent, transformed the way it is implemented $(22,23)$.

The COVID-19 pandemic caused a disruption in life as we were used to $(24,25,26,27)$, even in terms of education and even higher education. One example is the moments of transition to distance learning via the Internet and beyond (24, 28, 29 , 30,31 ), demonstrating the relevance, also, of social sciences in its apprehension and combat (25), and stressing the centrality of being organized and, at the same time, being prepared for the unexpected (32).

The teaching dimension (33) is very rewarding, for example, with the publication of Arends' (34) classic work - Learning to teach. It was crucial for me at the beginning. Classes with an active component are paramount, and I started to ascribe, over time and with greater experience, knowledge and confidence, increasing space for this type of classes $(21,35)$. In this case, the importance of at least sufficient general culture is critical (36).

Likewise, I felt the need for permanent updating (37), both in the way of teaching (38) and in terms of content. In the latter case, research and publication are vital. Publication entails the systematization of current knowledge (4).

The new digital conditions create new ways of life (39) and professionals $(40,41)$, as well as the open access of scientific publications as unavoidable in the scientific publication $(42,43)$. Less directly, reviewing papers reviews and belonging to editorial boards of scientific journals (for example http://bonoi.org/index.php/si/about/editorialTeam; https://publons.com/researcher/859777/sandro-serpa/) help to (i) systematize ideas, (ii) become aware of the most recent research in my scientific areas at the international level, (iii) create international networks of relationships; and (iv) convey information in a methodical way. All of this can and should, if relevant, be transported to teaching for the benefit of our students and our growing professional quality $(23,30,31,40)$.

\section{Conclusion}

From all this accrued experience, I draw, among others, the following conclusions of some relevant elements:

(i) Dialogue between sciences;

(ii) Interaction between persons;

(iii) Organization and, at the same time, preparedness for the unforeseen;

(iv) Classes with an active component;

(v) Importance of general culture;

(vi) Need for permanent updating;

(vii) Publishing implies knowledge systematization;

(viii) Open access as unavoidable in scientific publication.

After all this path, I do not believe we are in a situation of social disorder, but rather of hope that is less than fundamental, to which the COVID-19 pandemic contributed, albeit it was not the first nor the only factor.

In this context, Rawls's (44) reasoning, despite being somewhat dated, remains extremely current and continues to be one of my fundamental references already from my initial training, with the author's proposal of principles of justice based on a veil of ignorance. In summary,

The justice of a model of society depends essentially on the way how fundamental rights and duties are attributed, as well as on the economic opportunities and social conditions in the different sectors of society (44) (pp.30);

[...] an acceptable theory of justice should tell us which are our rights by telling us what clauses we would have stipulated to regulate the mode of cooperation between each other if we ignored everything that normally interferes with absolute impartiality (45) (pp.138)

In this circumstance, I firmly believe that the dissemination of scientific knowledge (37) is one of the mainstays of a society with greater social justice.

In sum, for an academic of these 20 years, I may conclude that teaching, research and publication seem critical to good professional performance to have a well-founded, knowledgeable and critical position of what one teaches. Following Flough (46) (pp.1), "People have started to see the fact that education is an essential key to a well-rounded development instead of the old mentality of just acquiring a degree and monetary success in life".

\section{References}

1. Serpa S. Introduction. S. Serpa, In 20 Years in the academia: A selection of works (pp5-pp8). Hydera-

bad, Telangana, India: Avid Science. eISBN: 978-93-88170-66-6. 2020. 
2. Javeau, C. Lições de Sociologia [Lessons of Sociology]. Oeiras: Celta Editora. 1998.

3. Singh CS, Redmond JMR, Wang F. Is science everything? Sci Insig 2015; 14(2):554-558. DOI: https://doi.org/10.15354/si.15.es003

4. Santos Al, Ferreira CM, Serpa S. Writing in science. J Educ Soc Res 2020; 10(4):128-133. DOI: https://doi.org/10.36941/jesr-2020-0072

5. Babalola SS, Nwanzu CL. The current phase of social sciences research: A thematic overview of the literature. Cogent Soc Sci 2021: 7(1):1892263. DOI: https://doi.org/10.1080/23311886.2021.1892263

6. Serpa S, Ferreira CM, Santos AI. Personal argumentation in the scholarly publication. J Educ Soc Res 2020: 10(2):1. DOI: https://doi.org/10.36941/jesr-2020-0021

7. Aron R. Max Weber. In R. Aron, As etapas do pensamento sociológico [The stages of sociological thought]. Lisboa: Publicações Dom Quixote. 1994.

8. Cruz MB. Max Weber. In M.B. Cruz, Teorias sociológicas Os fundadores e os clássicos [Sociological theories The founders and the classics]. Lisboa: Fundação Calouste Gulbenkian. 1995.

9. Galaz-Fontes JF, Arimoto A, Teichler U, Brennan J. (Eds.) Biographies and careers throughout academic life. Cham: Springer. 2016. DOI: http://dx.doi.org/10.1007/978-3-319-27493-5

10. Hodges C, Fowler D. COVID-19 crisis and faculty members in higher education: From emergency remote teaching to better teaching through reflection. Int J Multidiscip Persp Higher Educ 2021: 5(1):118-122. DOI: https://doi.org/10.32674/jimphe.v5i1.2507

11. Neves JG, Amorim FV, Frison LMB. O conceito de formação na pesquisa (auto)biográfica: $A$ complexidade como paradigma emergente e o método (auto)biográfico como síntese [The concept of training in (auto)biographical research: Complexity as an emerging paradigm and the (auto)biographical method as synthesis). Revista Eletrônica de Educação 2020; 14:3129095. DOI: https://doi.org/10.14244/198271993129

12. Ferreira $C$, Serpa $S$. Contemporary challenges for the academic. Int J Contemp Educ 2018; 2(1):1-8. DOI: http://dx.doi.org/10.11114/ijce.v2i1.3786

13. Sá MJ, Ferreira CM, Serpa S. (Un)professionalisation or (re)professionalisation of the academic in the brave new world? Postmodern Openings 2019; 10(2):84-113. DOI: https://doi.org/10.18662/po/73

14. Serpa S. An overview of the concept of organisational culture. Int Busin Manag 2016; 10(1):51-61.

15. Serpa S, Sá MJ, Ferreira CM. Organizational learning culture in effective improvement of educational organizations. Int J Educ Organiz Leader 2020; 27(1):47-68. DOI: https://doi.org/10.18848/2329-1656/CGP/v27i01/47-6 8

16. Cheung ACK, Slavin RE. Evidence-based reform in education: Responses to critics. Sci Insig Educ Front 2019; 2(1):65-69. DOI: https://doi.org/10.15354/sief.19.ar027
17. Serpa S. A reflection on sociology of education. Int $J$ Soc Sci Stud 2018; 6(3):33-39. DOI: https://doi.org/10.11114/ijsss.v6i3.3013

18. Serpa S, Sá MJ. Sociology of education for a sustainable future. Sustainability 2019, 11(6):1757, 1-5. https://doi.org/10.3390/su11061757

19. Serpa S, Ferreira CM, Santos Al. Fostering interdisciplinarity: Implications for social sciences. Int J Soc Sci Stud 2017; 5(12):44-49. DOI: https://doi.org/10.11114/ijsss.v5i12.2775

20. Sá MJ, Serpa S. Transversal competences: Their importance and learning processes by higher education students. Educ Sci 2018; 8(3):126, 1-12. DOI: https://doi.org/10.3390/educsci8030126

21. Ferreira CM, Serpa S. Challenges in the teaching of sociology in higher education. Contributions to a discussion. Societ Special Issue Train Model Pract Sociol 2017; 7(4):30, 1-11. DOI: https://doi.org/10.3390/soc7040030

22. Serpa S, Ferreira CM. Goffman's backstage revisited: Conceptual relevance in contemporary social interactions. Int J Soc Sci Stud 2018; 6(10):74-80. DOI: https://doi:10.11114/ijsss.v6i10.3659

23. Sá MJ, Santos Al, Serpa S. The academic supervisor of higher education students' final projects: A gatekeeper of quality? Acad J Interdiscip Stud 2021; 10(1):152-160. DOI: https://doi.org/10.36941/ajis-2021-0013

24. Sá MJ, Serpa S. The global crisis brought about by SARS-CoV-2 and its impacts on education: An overview of the Portuguese panorama. Sci Insig Educ Front 2020; 5(2):525-530. DOI: https://doi.org/10.15354/sief.20.ar039

25. Ferreira CM, Serpa S. (Eds.) COVID-19 and social sciences. Basel, Switzerland: MDPI. ISBN 978-3-0365-0154-3; elSBN 978-3-0365-0155-0. 2021. DOI: https://doi.org/10.3390/books978-3-0365-0155-0

26. BASE Medicine Task Force. COVID-19: Facts and recommendations from A to Z. Sci Insig 2020; 33(1):138-158. DOI: https://doi.org/10.15354/si.20.re061

27. BASE Medicine Task Force. Facts and recommendations of SARS-CoV-2 and COVID-19: An update. Sci Insig 2020; 35(1):194-215. DOI: https://doi.org/10.15354/si.20.re076

28. Yao J. We look forward to the future in the difficult days. Best Evid Chin Educ 2021; 7(1):891-892. DOI: https://doi.org/10.15354/bece.21.e003

29. Hannam-Swain S, Bailey C. Considering COVID-19: Autoethnographic reflections on working practices in a time of crisis by two disabled UK academics. SSRN Electron J 2020; DOI: https://doi.org/10.2139/ssrn.3596104

30. Sá MJ, Serpa S. The COVID-19 pandemic as an opportunity to foster the sustainable development of teaching in higher education. Sustainability 2020 12(20):8525, 1-16. DOI: https://doi.org/10.3390/su12208525

31. Sá MJ, Serpa S. Higher education in times of change: An overview. In M.J. Sá, \& S. Serpa, Higher educa- 
tion in times of change (pp7-pp9). Birmingham, United Kingdom: Services for Science and Education. 2020. DOI: https://doi.org/10.14738/eb.55.2020

32. Barbosa B, Borges MG, Serpa S. The Informal in the formal of organizations: The organizational structure in sociological analysis. Sci Insig 2021; 36(4):260-264. DOI: https://doi.org/10.15354/si.21.rp008

33. Tewari DD, Ilesanmi KD. Teaching and learning interaction in South Africa's higher education: Some weak links. Cogent Soc Sci 2020; 6(1):1740519. DOI: https://doi.org/10.1080/23311886.2020.1740519

34. Arends RI. Aprender a ensinar [Learning to teach]. Amadora: McGraw-Hill Portugal. 1999.

35. Santos AI, Serpa S. Flipped classroom for an active learning. J Educ E-Learn Res 2020; 7(2):167-173. DOI: https://doi.org/10.20448/journal.509.2020.72.167.173

36. Serpa S, Ferreira CM. Sociology: Tension between science and militant activism? J Educ Soc Res 2020; 10(6):1-8. DOI: https://doi.org/10.36941/jesr-2020-0105

37. Serpa S, Ferreira CM, Sá MJ, Santos AI. Dissemination of knowledge in the digital society. In S. Serpa, C. M. Ferreira, M. J. Sá, \& A. I. Santos, Digital society and social dynamics (pp2-pp16). Birmingham, United Kingdom: Services for Science and Education. 2020. DOI: https://doi.org/10.14738/eb.17.2020

38. Santos Al, Serpa S. The importance of promoting digital literacy in higher education. Int J Soc Sci Stud 2017; 5(6):90-93. DOI: https://doi.org/10.11114/ijsss.v5i6.2330
39. Ferreira CM, Serpa S. Society 5.0 and social development: Contributions to a discussion. Manag Organiz Stud 2018; 5(4):26-31. DOI: https://doi.org/10.5430/mos.v5n4p26

40. Sá MJ, Serpa S. Cultural dimension in internationalization of the curriculum in higher education. Educ Sci 2020; 10(12):375, 1-11. DOI: https://doi.org/10.3390/educsci10120375

41. Serpa S, José Sá M, Santos AI, Ferreira CM. Challenges for the academic editor in the scientific publication. Acad J Interdiscip Stud 2020; 9(3):12-16. DOI: https://doi.org/10.36941/ajis-2020-0037

42. Sá MJ, Ferreira CM, Serpa S. Science communication and online social networks: Challenges and opportunities. Knowled Manag Int J 2020; 19(2):1-22. DOI:

https://doi.org/10.18848/2327-7998/cgp/v19i02/1-22

43. Serpa S. A high-quality journal for a digital society. Sci Insig 2020; 35(3):222-223. DOI: https://doi.org/10.15354/si.20.ed039

44. Rawls J. Uma teoria da justiça. Lisboa: Editorial Presença (Original work: A theory of justice, published in 1971). 1993.

45. Ryan A. John Rawls. In Q. Skinner (Dir.), As ciências humanas e os seus grandes pensadores. Lisboa: Publicações Dom Quixote (Original work: The return of grand theory in the human sciences, published in 1985). 1992

46. Flough $\mathrm{S}$. The promising and unchangeable impact of education on life. Sci Insig 2018; 2018:1-4. DOI: https://doi.org/10.15354/si.18.vw008 